\title{
PENGARUH FASILITAS E-FILING DAN E-SPT TERHADAP KEPUASAN WAJIB PAJAK ORANG PRIBADI DALAM MELAPORKAN SPT (Studi Kasus Pada KPP Pratama Kota Batam)
}

\author{
Desrini Ningsih ${ }^{1 *}$, Fany Rahma Sari ${ }^{2}$, Heryenzus ${ }^{3}$ \\ Dosen Universitas Putera Batam \\ email: ningsihdesrini@gmail.com
}

\begin{abstract}
The Directorate General of Taxes has provided facilities to taxpayers to report taxes with SPT using e-Filing facilities and e-SPT. E-Filing is an application made by the directorate general of taxes so that taxpayers do not have to bother to queue at the tax service office. While e-SPT is also an application of services made by the directorate general of taxes for taxpayers to be able to report their taxes more easily and not consume a lot of paper. The study was conducted aimed to determine the effect of e-Filing and e-SPT facilities on the satisfaction of individual taxpayers in reporting SPT. The sample used was 400 using the purposive sampling method. The results of this study indicate that e-Filing and e-SPT facilities have a positive and significant influence on taxpayer satisfaction. Evident from the value of $t$ count is greater than t table. The value of t table is 1.966 while the value of $t$ count is obtained for the variable e-Filing facility (X1) 8.624 with a significance of 0,000 and the facility variable e-SPT (X2) 10,899 with a significance of 0,000. Result $F$ shows $F$ count 384,649 with a significant probability of 0,000 .
\end{abstract}

Keywords: E-Filing Facilities, E-SPT Facilities, Satisfaction Taxpayers

\section{PENDAHULUAN}

Pajak adalah pungutan wajib atas dasar perundang-undangan Republik Indonesia yang digunakan untuk kepentingan pemerintah dan masyarakat umum. Rakyat yang membayar pajak tidak akan merasakan manfaat dari pajak secara langsung karena pajak bukan digunakan untuk kepentingan umum. Self assessment yang dianut dalam sistem perpajakan di Indonesia menurut harta dan kewajiban sesuai dengan ketentuan peraturan perundang-undangan perpajakan (Pasal 1 UU KUP). Menurut data cnnindonesia.com (Indra, 2014) Direktorat Jenderal Pajak mencatat jumlah wajib pajak di Indonesia tahun 2014 sebanyak 60 juta individu dan 5 juta badan usaha. Namun dari jumlah tersebut, hanya 23 juta wajib pajak orang pribadi dan 550 ribu badan usaha yang taat membayar pajak. Jumlah masyarakat pemilik Nomor Pokok Wajib Pajak (NPWP) wajib pajak bertanggungjawab atas perhitungan, pelaporan, dan pembayaran pajaknya. Bentuk pertanggungjawaban itu terlihat dari keakuratan data yang dipaparkan dalam Surat Pemberitahuan (SPT), Tanpa adanya usaha untuk memanipulasi nominal dan sumber penghasilan. Surat Pemberitahuan (SPT) adalah surat yang oleh wajib pajak digunakan untuk melaporkan perhitungan, pembayaran pajak, objek pajak. Saat ini sekitar 28 juta orang, sementara yang patuh melaporkan Surat Pemberitahuan (SPT) baru sekitar 11 juta. Badan Pusat Statistik (BPS) mencatat pada 2013 terdapat sekitar 20 juta perusahaan yang beroperasi di Indonesia. Namun, berdasarkan analisis Direktorat Jenderal Pajak, baru sekitar 5 juta perusahaan yang wajib membayar pajak. Berdasarkan data yang dipaparkan oleh ortax.org jumlah pelapor SPT tahun 2015 lebih rendah dibandingkan dengan tren pelaporan SPT PPh dalam empat tahun terakhir. Hingga penutupan pelaporan SPT tanggal 31 maret 2015, wajib pajak yang menyerahkan SPT PPh orang pribadi jumlahnya tidak mencapai target 10 juta orang. Pada tahun 2012 jumlah pelaporan SPT 9,22 juta dari 17,65 juta wajib pajak yang terdaftar. Pada tahun 2013 jumlah pelapor sebanyak 9,8 juta dari 17,73 Wajib Pajak yang terdaftar, sedangkan pada tahun 2014 Wajib Pajak yang menyampaikan SPT sebanyak 10,78 juta dari 
18,35 wajib pajak yang terdaftar.

Pemberian fasilitas-fasilitas dalam menyampaikan SPT seperti e-filing dan e- SPT berperan penting dalam sistem perpajakan. Untuk dapat dengan sukses mencapai sasaran yang diharapkan dalam menghasilkan penerimaan pajak yang optimal dan juga memberikan kepuasan terhadap wajib pajak karena dapat membantu wajib pajak dalam melaksanakan kewajiban pajaknya. Banyak masyarakat yang ada di kota Batam memanfaatkan yang disediakan oleh Direktorat Jenderal Pajak seperti layanan fasilitas e-filing dan e-SPT karena para wajib pajak terkadang merasa malas datang ke Kantor Pelayanan Pajak (KPP) untuk melaporkan SPT karena alasan tidak ada waktu dan sibuk dengan pekerjaan masing-masing. Dengan adanya kedua fasilitas ini akan sangat mempermudah para wajib pajak untuk melaporkan SPT dengan tepat waktu agar tidak terkena sanksi akibat keterlambatan dalam melaporkan SPT nya.

Upaya dalam meningkatkan dan mengedepankan layanan e-filing dan e-SPT semakin terlihat berkembang dengan diberikannya fasilitas-fasilitas dalam menyampaikan SPT. Salah satunya perbaikan kualitas layanan dapat dilakukan dengan cara peningkatan kualitas dan kemampuan teknis pegawai dalam bidang perpajakan. Kualitas pelayanan yang baik akan berdampak pada kepuasan wajib pajak. Sehingga akan meningkatkan kepatuhan dan kesadaran untuk membayar pajaknya tepat waktu, sehingga pemasukan pajak dapat meningkat. Dengan meningkatnya kualitas layanan diharapkan dapat meningkatkan kepuasan wajib pajak. Masyarakat di kota Batam sangat terbantu dengan adanya fasilitas e-filing dan e-SPT. Karena mayoritas masyarakat di kota Batam adalah bekerja dan terkadang tidak sempat untuk datang langsung ke Kantor Pelayanan Pajak (KPP). Hal ini memang membantu masyarakat untuk meminimalisir waktu, tetapi karena fasilitas ini terhubung menggunakan sistem internet sering terjadi kesalahan error dan down pada saat pengisian SPT sedang dilakukan dan juga banyak masyarakat yang enggan melaporkan SPT tahunannya dengan alasan tidak mengerti tentang tata cara melaporkan e-SPT. Oleh sebab itu kepuasan masyarakat dalam menyampaikan SPT tidak maksimal, hal ini bisa berdampak kepada kepatuhan wajib pajak dalam melaporkan SPT nya.

\section{TINJAUAN PUSTAKA}

Definisi pajak menurut UU Nomor 16 tahun 2009 tentang perubahan keempat atas UU nomor 6 tahun 1983 tentang KUP (Ketentuan Umum dan Tata Cara perpajakan) Pasal 1 angka 1 UU KUP menyebutkan bahwa pajak adalah kontribusi wajib kepada negara yang terutang oleh orang pribadi atau badan yang bersifat memaksa berdasarkan undang-undang, dengan tidak mendapatkan imbalan secara langsung dan digunakan untuk keperluan negara dan sebesarbesarnya kemakmuran rakyat. Beberapa definisi perpajakan yang dikemukakan oleh para ahli berdasarkan sumber (Agoes, 2016). Pendapat pertama dari Soemitro pajak adalah iuran rakyat kepada kas negara berdasarkan undang-undang yang dapat dipaksakan dengan tidak mendapat timbal balik (kontraprestasi) yang langsung dapat ditunjukkan, dan digunakan untuk membayar pengeluaran umum.

Menurut Andriani pajak adalah iuran kepada kas negara (yang dapat dipaksakan) yang terutang oleh wajib pajak yang membayarnya menurut peraturan-peraturan, dengan tidak mendapat prestasi kembali, yang langsung dapat ditunjuk, dan yang gunanya adalah untuk membiayai pengeluaran-pengeluaran umum berhubung dengan tugas negara untuk menyelenggarakan pemerintahan. Menurut Smeets (2012) pajak adalah prestasi kepada pemerintah yang terutang melalui norma-norma umum, dan yang dapat dipaksakan, tanpa adanya kontraprestasi yang dapat ditunjukkan secara individual, maksudnya adalah untuk membiayai pengeluaran pemerintah. Dari definisi tersebut dapat ditarik kesimpulan bahwa: (a) pajak dipungut berdasarkan dengan kekuatan undang-undang serta aturan pelaksanaannya; (b) dalam pembayaran pajak tidak dapat ditunjukkan adanya kontraprestasi individual oleh pemerintah; (c) pajak dipungut oleh negara baik pemerintah pusat maupun daerah; (d) pajak diperuntukkan bagi pengeluaran-pengeluaran negara; (e) dapat dipaksakan.

Menurut (Hidayat, 2013) Surat Pemberitahuan (SPT) adalah surat yang oleh wajib pajak digunakan untuk melaporkan penghitungan dan pembayaran pajak, objek atau bukan objek pajak, dan harta dan kewajiban sesuai dengan ketentuan peraturan perundang-undangan 
perpajakan (Pasal 1 UU KUP). Menurut (Murtopo, 2011) SPT berfungsi untuk melaporkan seluruh kewajiban perpajakan para wajib pajak. Dari SPT yang diisi sendiri oleh wajib pajak itu dapat diketahui kewajiban pajak dan sebagai alat dirjen pajak untuk mengetahui kewajiban perpajakan wajib pajak. Apabila ada wajib pajak yang tidak melaporkan SPT tidak peduli wajib pajak tersebut sudah membayarkan pajaknya ke kas negara, dirjen pajak akan menganggap wajib pajak belum membayar pajak. Menurut (Lubis, 2011) fungsi SPT bagi wajib pajak adalah sebagai sarana untuk:

1. Melaporkan, mempertanggungjawabkan perhitungan jumlah pajak yang sebenarnya terutang

2. Melaporkan tentang pemenuhan pembayaran pajak yang telah dilaksanakan sendiri dalam tahun pajak atau pagian tahun pajak

3. Melaporkan pembayaran dari pemotong atau pemungut tentang pemotongan/pemungutan pajak orang atau badan lain dalam satu masa pajak

Berdasarkan peraturan Direktorat Jenderal Pajak (DJP) nomor PER-1/PJ/2014 e-Filing adalah suatu cara penyampaian SPT tahunan atau pemberitahuan perpanjangan SPT tahunan yang dilakukan secara online yang real time melalui Penyedia Jasa Aplikasi atau Application Service Provider (ASP). Menurut (Kirana, 2010) wajib pajak yang menggunakan sistem e-filing ini mendapatkan perlindungan hukum. Direktorat jenderal pajak dapat memberikan jaminan kepada wajib pajak atas keamanan, kerahasiaan dan keasliannya. Tanda tangan digital yang dibubuhkan dalam e-SPT merupakan proses penyisipan status subjek hukum pada informasi, bahwa pengirim informasi adalah subjek hukum yang benar.

Menurut (Pandiangan, 2008) e-SPT adalah penyampaian dalam bentuk digital ke KPP secara elektronik atau dengan media komputer. Sedangkan pengertian menurut Direktorat Jenderal Pajak (DJP) e-SPT adalah surat pemberitahuan beserta lampiran- lampirannya dalam bentuk digital dan dilaporkan secara elektronik dengan menggunakan komputer yang digunakan untuk membantu wajib pajak dalam melaporkan penghitungan dan pembayaran pajak yang terutang sesuai dengan ketentuan peraturan perundang-undangan yang berlaku. Berdasarkan pengertian di atas, maka disimpulkan bahwa e-SPT adalah suatu program yang dapat digunakan oleh wajib pajak untuk melakukan pengisian dan pelaporan SPT secara tepat, tepat dan akurat.

Menurut Direktorat Jenderal Pajak (DJP) seperti yang dikutip dari www.pajak.go.id eSPT juga memiliki manfaat sama seperti e- filing. Dengan adanya modernisasi pajak dan e-SPT sebagai salah satunya, maka e-SPT sebagai program aplikasi yang berguna untuk mempermudah wajib pajak dalam melakukan pelaporan perpajakannya. Berikut adalah beberapa manfaatnya:

1. Penyampaian SPT dapat dilkukan secara cepat dan aman, karena lampiran dalam bentuk media $\mathrm{CD} /$ disket

2. Data perpajakan terorganisir dengan baik

3. Mengorganisir data perpajakan perusahaan dengan baik dan sistematis

4. Perhitungan dilakukan secara tepat dan cepat karena menggunakan computer

5. Kemudahan dalam membuat laporan pajak

6. Data yang disampaikan wajib pajak selalu lengkap, karena penomoran formulir dengan menggunakan computer

7. Menghindari pemborosan penggunaan kertas

8. Berkurangnya pekerjaan-pekerjaan perekaman SPT yang memakan sumber daya cukup banyak

Menurut (Supranto, 2011) kepuasan konsumen merupakan label yang yang digunakan label yang digunakan oleh kunsumen untuk meringkas suatu himpunan aksi atau tindakan yang terlihat, terkait produk atau jasa. Seorang pengguna yang merasa puas adalah pengguna yang merasa mendapatkan value dari pemasok, produsen, aparatur pajak yang dapat diukur secara kuantitatif dan kualitatif atas pelayanan yang diberikan. Pelayanan yang diberikan oleh DJP untuk senantiasa menunaikan kewajiban kita sebagai warga negara untuk membayar pajak dengan menggunakan fasilitas-fasilitas yang telah disediakan untuk menyampaikan SPT yang 
memudahkan serta aman dan terjaga kerahasiaannya sehingga wajib pajak dan penyedia jasa. Value ini biasa berasal dari produk, pelayanan, sistem atau sesuatu yang bersifat pun merasa puas atas pelayanan yang telah disediakan Menurut (Irawan, 2011) dalam konsep ServQual, konsep pelayanan terdiri dari 5 yaitu:

1. Tangible, merupakan aspek penting dalam pengukuran terhadap pelayanan karena pelanggan akan menggunakan indera penglihatan untuk menilai suatu kualitas pelayanan.

2. Reliability, merupakan elemen yang mengukur keandalan dari perusahaan, dalam memberikan pelayanan kepada pelanggannya.

3. Responsiveness, merupakan kemauan untuk membantu dan memberikan jasa dengan cepat kepada pelanggan.

4. Assurance, merupakan elemen kualitas yang berhubungan dengan kemampuan perusahaan dan perilaku front-line staff dalam menanamkan rasa percaya dan keyakinan kepada para pelanggan.

5. Empathy, merupakan kesediaan untuk peduli dan memberikan perhatian pribadi kepada pengguna jasa.

Seperti yang telah disebutkan di atas terdapat 5 indikator dalam kepuasan pelanggan. Karena fasilitas e-filing dan fasilitas e-SPT hanya dapat digunakan secara online maka indikator yang dapat kita pakai adalah responsiveness, walaupun hanya menggunakan satu indikator, tetapi terdapat beberapa item yang bisa dimasukkan kedalam responsiveness.

Tabel 1. Penelitian Terdahulu

\begin{tabular}{|c|c|c|c|}
\hline No & Penelitian & Judul Penelitian & Hasil \\
\hline 1. & $\begin{array}{l}\text { Tumuli, Sondakh, } \\
\text { dan Wokas } \\
(2016)\end{array}$ & $\begin{array}{l}\text { Pengaruh penerapan e-SPT dan } \\
\text { Penerapan e-filing dalam } \\
\text { upaya peningkatan kepatuhan } \\
\text { wajib pajak }\end{array}$ & $\begin{array}{l}\text { Penerapan e-SPT dan e-filing } \\
\text { berhasil meningkatkan kepatuhan } \\
\text { wajib pajak dalam menyampaikan } \\
\text { SPT Tahunan }\end{array}$ \\
\hline 2. & $\begin{array}{l}\text { Rizki Fitri Amalia } \\
(2016)\end{array}$ & $\begin{array}{|lc|}\text { Pengaruh penerapan } & \text { e-filing } \\
\text { terhadap tingkat } & \text { kepatuhan } \\
\text { penyampaian SPT } & \text { tahunan } \\
\text { wajib pajak orang } & \text { pribadi } \\
\text { dengan pelayanan } & \text { account } \\
\text { representative } & \text { sebagai } \\
\text { variable intervening } & \end{array}$ & $\begin{array}{l}\text { Pelayanan account representative } \\
\text { dalam melayani dan memberikan } \\
\text { peranan penting bagi kemudahan } \\
\text { pelaporan perpajakan yang } \\
\text { mempengaruhi penerimaan pajak } \\
\text { idan kepatuhan wajib pajak. }\end{array}$ \\
\hline 3. & $\begin{array}{l}\text { Danar Kiswara dan } \\
\text { I Ketut Jati (2016) }\end{array}$ & $\begin{array}{l}\text { Pengaruh penerapan e-filing } \\
\text { dan account representative } \\
\text { terhadap pencitraan otoritas } \\
\text { pajak dan kepatuhan wajib } \\
\text { pajak }\end{array}$ & $\begin{array}{l}\text { Ditemukan bahwa peran e-Filing } \\
\text { dan AR berpengaruh signifikan } \\
\text { terhadap pencitraan otoritas } \\
\text { kepatuhan wajib pajak }\end{array}$ \\
\hline 4. & $\begin{array}{l}\text { Ita } \\
\text { Lingga } \\
(2012)\end{array}$ & $\begin{array}{l}\text { Pengaruh penerapan e-SPT } \\
\text { terhadap efisiensi pemrosesan } \\
\text { data perpajakan: survey } \\
\text { terhadap pengusaha kena pajak } \\
\text { pada KPP Pratama Bandung }\end{array}$ & 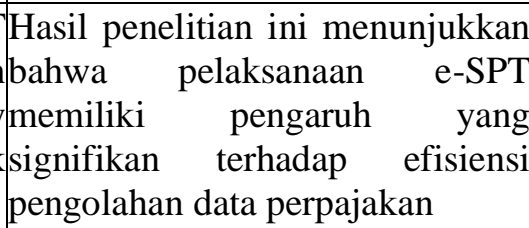 \\
\hline
\end{tabular}

$\mathrm{H}_{1}$ : Fasilitas e-filing berpengaruh signifikan terhadap kepuasan wajib pajak orang pribadi dalam melaporkan SPT

$\mathrm{H}_{2}$ : Fasilitas e-SPT berpengaruh signifikan terhadap kepuasan wajib pajak orang pribadi dalam melaporkan SPT

$\mathrm{H}_{3}$ : Fasilitas e-filing dan e-SPT secara simultan berpengaruh signifikan terhadap kepuasan wajib pajak orang pribadi dalam melaporkan SPT. 


\section{METODE}

Desain penelitian dalam penelitian ini merupakan penelitian kuantitatif. Penelitian kuantitatif dalam melihat hubungan variabel terhadap objek yang diteliti lebih bersifat sebab dan akibat (kausal), sehingga dalam penelitiannya ada variabel independen dan dependen. Dari variabel tersebut selanjutnya dicari seberapa besar pengaruh variabel independen terhadap variabel dependen (Sugiyono, 2015).

Populasi dalam penelitian ini adalah seluruh wajib pajak terdaftar di KPP Pratama Kota Batam, dan sampel yang di ambil sebanyak 400 responden. Teknik pengambilan sampel yang digunakan adalah purposive sampling. Tujuan penelitian ini adalah untuk mengetahui, menganalisis suatu fenomena yang ada. Untuk penelitian ini peneliti membutuhkan alat ukur atau skala atau seperangkat alat uji untuk mengukur dan memaknai apa yang akan diteliti. Data yang diperoleh melalui prosedur pengumpulan data dianalisis dengan menggunakan uji validitas dan reabilitas.

Uji validitas digunakan untuk mengukur sah atau valid tidaknya suatu kuesioner. Suatu kuesioner dikatakan valid jika pertanyaan pada kuesioner mampu untuk mengungkapkan sesuatu yang akan diukur oleh kuesioner tersebut (Ghozali, 2016). Uji reliabilitas dilakukan dengan menggunakan Cronbach Alpha $(\alpha)$. Suatu variabel dikatakan reliabel jika memberikan nilai Cronbach Alpha $>0,70$ (Ghozali, 2016). Hipotesis yang dirumuskan akan diuji dengan Statistik Parametris, antara lain dengan menggunakan t-test untuk satu sampel, korelasi dan regresi, analisis varian dan t-test untuk dua sampel. Penggunaan statistik parametris mensyaratkan bahwa data setiap variabel yang akan dianalisis harus berdistribusi normal. Pengujian normalitas dalam penelitian ini menggunakan Normal P-P Plot of Regresion Standarized Residual yang membandingkan distribusi kumulatif dari data sesungguhnya dengan distribusi kumulatif dari data normal.

Untuk mendeteksi ada atau tidak multikolinearitas di dalam model regresi pada penelitian ini mengguanakan besaran VIF (Variance Inflation Factor) dan tolerance. Uji heteroskedastisitas bertujuan untuk menguji apakah model regresi terjasi ketidaksamaan dari residual satu pengamatan ke pengamatan lain. Jika residual satu pengamatan kepengamatan lain tetap, maka disebut homoskedastisitas dan jika berbeda disebut heteroskedastisitas.

\section{HASIL DAN PEMBAHASAN \\ Isi Hasil dan Pembahasan}

Pengolahan data dalam penelitian ini dilakukan dari hasil penyebaran kuesioner ke wajib pajak yang menggunakan e-Filing dan e-SPT. Jumlah penyebaran dan pengumpulan kuesioner dibagikan kepada 400 responden. Profil responden dalam penelitian ini dapat dilihat berdasarkan Jenis kelamin, Usia, Pendidikan terakhir dan profesi pekerjaan.

Untuk tingkat capaian jawaban responden terhadap tiap item pernyataan variabel eFiling dapat dilihat pada tabel berikut.

Tabel 2. Hasil Analisis Deskriptif E-Filing (X1)

\begin{tabular}{|c|c|c|c|}
\hline Pernyataan & $\begin{array}{c}\text { Nilai Rata-Rata Pencapaian } \\
\text { Jawaban Responden }\end{array}$ & $\begin{array}{c}\text { Rentang Kriteria Nilai } \\
\text { Penafsiran }\end{array}$ & $\begin{array}{c}\text { Keteranga } \\
\text { n }\end{array}$ \\
\hline X1.1 & 3,35 & $2,60-3,39$ & Cukup \\
\hline X1.2 & 2,64 & $2,60-3,39$ & Cukup \\
\hline X1.3 & 3,73 & $3,40-4,19$ & Baik \\
\hline X1.4 & 3,56 & $3,40-4,19$ & Baik \\
\hline X1.5 & 3,15 & $2,60-3,39$ & Cukup \\
\hline X1.6 & 3,73 & $3,40-4,19$ & Baik \\
\hline
\end{tabular}

Untuk tingkat capaian jawaban responden terhadap tiap item pernyataan hasil uji variabel e-SPT dapat dilihat pada table berikut ini. 
Tabel 3. Hasil Analisis Deskriptif E-SPT (X2)

\begin{tabular}{|c|c|c|c|}
\hline Pernyataan & $\begin{array}{c}\text { Nilai Rata-Rata Pencapaian } \\
\text { Jawaban Responden }\end{array}$ & $\begin{array}{c}\text { Rentang Kriteria Nilai } \\
\text { Penafsiran }\end{array}$ & Keterangan \\
\hline X2.1 & 3,73 & $3,40-4,19$ & Baik \\
\hline X2.2 & 3,73 & $3,40-4,19$ & Baik \\
\hline X2.3 & 3,05 & $2,60-3,39$ & Cukup \\
\hline X2.4 & 3,73 & $3,40-4,19$ & Baik \\
\hline X2.5 & 3,31 & $2,60-3,39$ & Cukup \\
\hline X2.6 & 3,73 & $3,40-4,19$ & Baik \\
\hline
\end{tabular}

Untuk tingkat capaian jawaban responden terhadap tiap item pernyataan variabel kepuasan wajib pajak orang pribadi dalam melaporkan SPT dapat dilihat pada tabel 4 di bawah ini.

Tabel 4. Hasil Analisis Deskriptif Kepuasan Wajib Pajak Orang Pribadi dalam Melaporkan SPT

(Y)

\begin{tabular}{|c|c|c|c|}
\hline Pernyataan & $\begin{array}{c}\text { Nilai Rata-Rata Pencapaian } \\
\text { Jawaban Responden }\end{array}$ & $\begin{array}{c}\text { Rentang Kriteria Nilai } \\
\text { Penafsiran }\end{array}$ & Keterangan \\
\hline Y1 & 3,12 & $2,60-3,39$ & Cukup \\
\hline Y2 & 4,08 & $3,40-4,19$ & Baik \\
\hline Y3 & 3,56 & $3,40-4,19$ & Baik \\
\hline Y4 & 4,08 & $3,40-4,19$ & Baik \\
\hline Y5 & 3,64 & $3,40-4,19$ & Baik \\
\hline Y6 & 3,73 & $3,40-4,19$ & Baik \\
\hline
\end{tabular}

Tabel hasil uji realibilitas dapat dilihat pada table berikut ini.

Tabel 5. Hasil Uji Realibilitas

\begin{tabular}{|c|c|c|c|}
\hline Variabel & $\begin{array}{c}\text { Cronbach's } \\
\text { Alpha }\end{array}$ & $\begin{array}{c}\mathbf{r}_{\text {tabel }} \\
5 \%(\mathrm{~N}=372)\end{array}$ & Keterangan \\
\hline Fasilitas E-Filing (X1) & 0,782 & \multirow[b]{3}{*}{0,101} & Reliabel \\
\hline Fasilitas $E-S P T(\mathrm{X} 2)$ & 0,810 & & Reliabel \\
\hline $\begin{array}{l}\text { Kepuasan Wajib Pajak } \\
\text { Orang Pribadi dalam } \\
\text { Melaporkan SPT(Y) }\end{array}$ & 0,793 & & Reliabel \\
\hline
\end{tabular}

Berdasarkan hasil analisis data pada tabel uji reabilitas tersebut dapat disimpulkan bahwa item-item pernyataan pada masing- masing variabel penelitian dikatakan reliabel. Hal ini dibuktikan oleh nilai $r$ hitung (Cronbach's Alpha) $>r$ tabel $(0,101$ diperoleh dari persamaan $n-$ $2=374-2=372$ ). 
Hasil pengujian validitas data terlihat pada table berikut ini.

Tabel 6. Hasil Uji Validitas

\begin{tabular}{|c|c|c|c|c|}
\hline Variabel & $\begin{array}{c}\text { Item } \\
\text { Pernyataan }\end{array}$ & $\mathbf{r}_{\text {hitung }}$ & $\begin{array}{c}\mathbf{r}_{\text {tabel }} \\
\mathbf{5 \%}(\mathrm{N}=\mathbf{3 7 2})\end{array}$ & Keterangan \\
\hline \multirow{6}{*}{$\begin{array}{l}\text { Fasilitas } \\
\text { E-Filing }\end{array}$} & $\mathrm{X} 1.1$ & 0,699 & \multirow{18}{*}{0,101} & Valid \\
\hline & $\mathrm{X} 1.2$ & 0,681 & & Valid \\
\hline & $\mathrm{X} 1.3$ & 0,715 & & Valid \\
\hline & $\mathrm{X} 1.4$ & 0,606 & & Valid \\
\hline & $\mathrm{X} 1.5$ & 0,730 & & Valid \\
\hline & X1.6 & 0,684 & & Valid \\
\hline \multirow{6}{*}{$\begin{array}{c}\text { Fasilitas } \\
E-S P T\end{array}$} & $\mathrm{X} 2.1$ & 0,711 & & Valid \\
\hline & $\mathrm{X} 2.2$ & 0,756 & & Valid \\
\hline & $\mathrm{X} 2.3$ & 0,665 & & Valid \\
\hline & $\mathrm{X} 2.4$ & 0,722 & & Valid \\
\hline & $\mathrm{X} 2.5$ & 0,672 & & Valid \\
\hline & $\mathrm{X} 2.6$ & 0,697 & & Valid \\
\hline \multirow{3}{*}{ Kepuasan Wajib } & Y1 & 0,731 & & Valid \\
\hline & Y2 & 0,696 & & Valid \\
\hline & Y3 & 0,697 & & Valid \\
\hline \multirow{3}{*}{$\begin{array}{c}\text { Pajak Orang Pribadi } \\
\text { dalam Melaporkan } \\
\text { SPT }\end{array}$} & Y4 & 0,675 & & Valid \\
\hline & Y5 & 0,679 & & Valid \\
\hline & Y6 & 0,673 & & Valid \\
\hline
\end{tabular}

Berdasarkan data pada tabel 6 dapat dilihat bahwa hasil uji validitas untuk semua butir pernyataan mempunyai nilai $\mathrm{r}$ hitung $>\mathrm{r}$ tabel, dengan taraf signifikan $\alpha=0,05$ dan derajat bebas $(\mathrm{dk}=\mathrm{n}-2)$ dapat disimpulkan bahwa semua pernyataan pada penelitian ini dinyatakan valid.

Hasil uji Kolmogorov Smirnov yang dapat dilihat pada tabel 7 berikut diketahui nilai Asymp. Sig. (2-tailed) sebesar 0,078>0,05 (alpha) sehingga dapat disimpulkan bahwa data mempunyai sebaran atau distribusi yang normal.

Tabel 7. Hasil Uji Normalitas dengan kolmogorov smirnov One-Sample Kolmogorov-Smirnov Test

\begin{tabular}{|ll|r|}
\hline & & Unstandardized Residual \\
\hline $\mathrm{N}$ & & 374 \\
Normal Parameters ${ }^{\mathrm{a}, \mathrm{b}}$ & Mean & .0000000 \\
& & 2.13012889 \\
Most Extreme Differences & Std. Deviation & .044 \\
& Absolute & .040 \\
& Positive & -.044 \\
Test Statistic & Negative & .044 \\
Asymp. Sig. (2-tailed) & & $.078^{\mathrm{c}}$ \\
\hline
\end{tabular}

a. Test distribution is Normal.

b. Calculated from data.

c. Lilliefors Significance Correction. 
Untuk hasil uji heteroskedastisitas dapat dilihat pada tabel berikut.

Tabel 8. Hasil Uji Heterokedastisitas

Coefficients $^{\mathrm{a}}$

\begin{tabular}{|c|c|c|c|c|c|c|}
\hline \multirow{2}{*}{\multicolumn{2}{|c|}{ Model }} & \multicolumn{2}{|c|}{ Unstandardized Coefficients } & $\begin{array}{l}\text { Standardized } \\
\text { Coefficients }\end{array}$ & \multirow[t]{2}{*}{$\mathrm{T}$} & \multirow[t]{2}{*}{ Sig. } \\
\hline & & $\mathrm{B}$ & Std. Error & Beta & & \\
\hline & (Constant) & .941 & .173 & & .000 & 1.000 \\
\hline & Fasilitas E-Filing & .000 & .007 & .000 & .000 & 1.000 \\
\hline & Fasilitas $E-S P T$ & .000 & .012 & .000 & .000 & 1.000 \\
\hline
\end{tabular}

a. Dependent Variable: ABS_RES

Suatu model dikatakan tidak mengalami gejala heteroskedastisitas jika nilai probabilitas atau signifikansi lebih dari 0,05. Berdasarkan table tersebut diketahui bahwa nilai probabilitas atau signifikansi dari masing-masing variabel sebesar 1,000 maka dapat disimpulkan bahwa dalam model regresi penelitian ini tidak terdapat gejala heteroskedastisitas.

Selanjutnya hasil uji multikolinearitas terlihat pada tabel berikut.

Tabel 9. Hasil Uji Multikolonieritas

\section{Coefficients $^{\mathrm{a}}$}

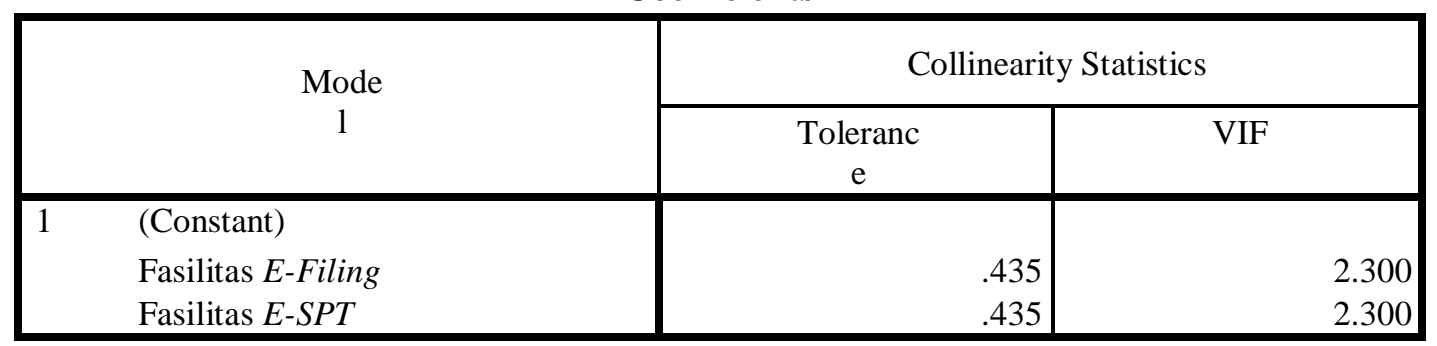

a. Dependent Variable: Kepuasan Wajib Pajak Orang Pribadi dalam Melaporkan SPT

Tabel tersebut menunjukkan bahwa nilai VIF untuk variabel X1 dan X2 sebesar 2,300 sehingga dapat disimpulkan bahwa dalam model regresi tidak terdapat gejala multikolonieritas antar variabel bebas karena nilai VIF nya lebih kecil dari 10 yang berarti bahwa semua variabel tersebut dapat digunakan sebagi variabel yang saling independen.

Tabel 10. Hasil Uji Analisis Regresi Linier Berganda Coefficients $^{\mathrm{a}}$

\begin{tabular}{|c|c|c|c|c|c|c|}
\hline \multirow{2}{*}{\multicolumn{2}{|c|}{ Model }} & \multicolumn{2}{|c|}{$\begin{array}{l}\text { Unstandardized } \\
\text { Coefficients }\end{array}$} & $\begin{array}{l}\text { Standardized } \\
\text { Coefficients }\end{array}$ & \multirow[t]{2}{*}{$\mathrm{T}$} & \multirow[t]{2}{*}{ Sig. } \\
\hline & & $\mathrm{B}$ & Std. Error & Beta & & \\
\hline \multirow[t]{3}{*}{1} & (Constant) & 4.318 & .656 & & 6.584 & .000 \\
\hline & Fasilitas E-Filing & .380 & .044 & .387 & 8.624 & .000 \\
\hline & Fasilitas $E-S P T$ & .480 & .044 & .489 & 10.899 & .000 \\
\hline
\end{tabular}

a. Dependent Variable: Kepuasan Wajib Pajak Orang Pribadi dalam Melaporkan SPT berikut:

Berdasarkan table 4.18 dapat diperoleh persamaan regresi linear berganda sebagai $\mathrm{Y}=4,318+0,380 \mathrm{X} 1+0,480 \mathrm{X} 2+\mathrm{e}$

Untuk pengujian hipotesis, yang dilihat dari uji t dapat dilihat pada tabel di bawah ini. 
Tabel 11. Hasil Uji t

Coefficients $^{\mathrm{a}}$

\begin{tabular}{|c|c|c|c|c|c|c|}
\hline \multirow{2}{*}{\multicolumn{2}{|c|}{ Model }} & \multicolumn{2}{|c|}{$\begin{array}{l}\text { Unstandardized } \\
\text { Coefficients }\end{array}$} & $\begin{array}{l}\text { Standardized } \\
\text { Coefficients }\end{array}$ & \multirow[t]{2}{*}{$\mathrm{T}$} & \multirow[t]{2}{*}{ Sig. } \\
\hline & & $\mathrm{B}$ & Std. Error & Beta & & \\
\hline \multirow[t]{3}{*}{1} & (Constant) & 4.318 & .656 & & 6.584 & .000 \\
\hline & Fasilitas E-Filing & .380 & .044 & .387 & 8.624 & .000 \\
\hline & Fasilitas $E-S P T$ & .480 & .044 & .489 & 10.899 & .000 \\
\hline
\end{tabular}

Pengujian terhadap variabel fasilitas e- filing (X1) memperoleh nilai koefisiensi 0,380 berpengaruh secara positif terhadap kepuasan wajib pajak orang pribadi dalam melaporkan SPT. Nilai signifikan sebesar 0,000 $<0,05$ (nilai alpha) menunjukkan adanya hubungan yang signifikan antara fasilitas e-filing (X1) dengan kepuasan wajib pajak orang pribadi dalam melaporkan SPT. Hasil t hitung 8,624 > t tabel 1,966 semakin memperkuat hasil uji variabel fasilitas e- filing (X1) yaitu berpengaruh secara positif dan signifikan terhadap kepuasan wajib pajak orang pribadi dalam melaporkan SPT. Pengujian terhadap variabel fasilitas e-SPT (X2) memperoleh nilai koefisiensi 0,380 berpengaruh secara positif terhadap kepuasan wajib pajak orang pribadi dalam menyampaikan SPT. Nilai signifikan sebesar 0,000 $<0,05$ (nilai alpha) menunjukkan adanya hubungan yang signifikan antara fasilitas e-filing (X2) dengan kepuasan wajib pajak orang pribadi dalam menyampaikan SPT. Hasil t hitung 10,899 $>\mathrm{t}$ tabel 1,966 semakin memperkuat hasil uji variabel fasilitas e-SPT (X2) yaitu berpengaruh secara positif dan signifikan terhadap kepuasan wajib pajak orang pribadi dalam menyampaikan SPT.

Tabel 12. Hasil Uji F ANOVA $^{\text {a }}$

\begin{tabular}{|ll|r|r|r|r|r|}
\hline Model & & Sum of Squares & Df & Mean Square & \multicolumn{1}{|c|}{ F } & \multicolumn{1}{c|}{ Sig. } \\
\hline 1 & Regression & 3509.470 & 2 & 1754.735 & 384.649 & $.000^{\mathrm{b}}$ \\
& Residual & 1692.469 & 371 & 4.562 & & \\
& Total & 5201.939 & 373 & & & \\
\hline
\end{tabular}

a. Dependent Variable: Kepuasan Wajib Pajak Orang Pribadi dalam Melaporkan SPT

b. Predictors: (Constant), Fasilitas E-SPT, Fasilitas E-Filing

Tingkat kepuasan yang diinterprestasikan oleh pengaruh fasilitas e-filing dan fasilitas eSPT secara bersama-sama memiliki pengaruh yang positif dan signifikan terhadap kepuasan wajib pajak orang pribadi dalam melaporkan SPT di Kota Batam. Hasil penelitian menunjukkan bahwa tingkat nilai signifikan $0,000<0,05$ sehingga dapat disimpulkan fasilitas e-filing dan fasilitas e-SPT secara bersama-sama memiliki pengaruh yang positif dan signifikan terhadap kepuasan wajib pajak orang pribadi dalam melaporkan SPT di kota Batam.

Tabel 17. Hasil Uji Determinan $\left(\mathrm{R}^{2}\right)$

Model Summary

\begin{tabular}{|l|r|r|r|r|}
\hline Model & R & \multicolumn{1}{|c|}{ R Square } & Adjusted R Square & Std. Error of the Estimate \\
\hline 1 & $.821^{\mathrm{a}}$ & .675 & .673 & 2.13586 \\
\hline
\end{tabular}

a. Predictors: (Constant), Fasilitas E-SPT, Fasilitas E-Filing

b. Dependent Variable: Kepuasan Wajib Pajak Orang Pribadi dalam Melaporkan SPT

Tabel tersebut memperlihatkan hasil pengujian nilai R Square sebesar 0,675 menunjukkan bahwa $67,5 \%$ dari kepuasan wajib pajak orang pribadi dalam melaporkan SPT dapat dijelaskan JURNAL AKUNTANSI BARELANG 
oleh variabel fasilitas e-filing dan fasilitas e-SPT. Sedangkan sisanya sebesar 32,5\% dijelaskan oleh variabel-variabel lain yang tidak dimasukkan dalam model penelitian ini.

\section{Pembahasan}

Variabel fasilitas e-filing (X1) berpengaruh secara positif dan signifikan terhadap kepuasan wajib pajak orang pribadi dalam melaporkan SPT. Karena E-filing merupakan layanan pengisian dan penyampaian surat pemberitahuan wajib pajak secara elektronik kepada Direktorat Jenderal Pajak, dengan memanfaatkan jalur komunikasi internet. Dengan adanya sistem ini, para wajib pajak akan lebih mudah menunaikan kewajibannya tanpa harus mengantri di kantor pelayanan pajak sehingga dirasa lebih efektif dan efisien. Hal ini akan membantu memangkas biaya dan waktu yang dibutuhkan wajib pajak untuk mempersiapkan, memproses dan melaporkan Surat Pemberitahuan ke Kantor Pelayanan Pajak secara benar dan tepat waktu, sehingga dapat memberikan kepuasan pada wajib pajak dalam menyampaikan kewajiban perpajakannya.

Variabel fasilitas e-SPT (X2) yaitu berpengaruh secara positif dan signifikan terhadap kepuasan wajib pajak orang pribadi dalam menyampaikan SPT. Karena e-SPT merupakan aplikasi (software) yang dibuat oleh Direktorat Jendral Pajak untuk digunakan oleh Wajib Pajak untuk kemudahan dalam penyampaian Surat Pemberitahuan (SPT). Penggunaan e-SPT dimaksudkan agar semua proses kerja dan pelayanan perpajakan berjalan dengan baik, lancar, dan akurat serta mempermudah wajib pajak dalam melaksanakan kewajiban perpajakannya. Tentu saja hal ini berdampak pada meningkatnya kepuasan wajib pajak karena e-SPT mempermudah dalam penyampaian Surat Pemberitahuan (SPT).

\section{SIMPULAN}

Berdasarkan hasil penelitian dan pembahasan dapat diambil beberapa kesimpulan yaitu: terdapat pengaruh positif dan signifikan fasilitas e-filing terhadap kepuasan wajib pajak orang pribadi dalam melaporkan SPT pada KPP Pratama Kota Batam, hal ini ditunjukkan dari hasil uji parsial dengan diperoleh $\mathrm{t}$ hitung yang lebih besar dari $\mathrm{t}$ tabelnya ( $\mathrm{t}$ hitung 8,624 $>\mathrm{t}$ tabel 1,966) dengan nilai signifikansi sebesar $0,000<0,05$ (nilai alpha). Terdapat pengaruh positif dan signifikan fasilitas e-SPT terhadap kepuasan wajib pajak orang pribadi dalam melaporkan SPT pada KPP Pratama Kota Batam, hal ini ditunjukkan dari hasil uji parsial dengan diperoleh nilai $t$ hitung yang lebih besar dari $t$ tabelnya ( $t$ hitung 10,899 $>\mathrm{t}$ tabel 1,966) dengan nilai signifikansi sebesar $0,000<0,05$ (nilai alpha). Terdapat pengaruh secara simultan fasilitas efiling dan fasilitas e-SPT terhadap kepuasan wajib pajak orang pribadi dalam melaporkan SPT pada KPP Pratama Kota Batam, hal ini ditunjukkan dengan nilai signifikansi sebesar 0,000< 0,05 (nilai alpha).

\section{DAFTAR PUSTAKA}

Agoes, S. (2016). Akuntansi Perpajakan (ketiga). Jakarta: Salemba Empat.

Fitri Amalia, R. (2016). Pengaruh Penerapan E-Filing Terhadap Tingkat Kepatuhan Penyampaian SPT Tahunan Pajak Penghasilan Wajib Pajak Orang Pribadi Dengan Pelayanan Account Representative Sebagai Variabel Intervening, Volume 15.

Ghozali, I. (2016). Aplikasi Analisis MultivariateDengan ProgramIBM SPSS 23 (Edisi 8). Semarang: UNDIP.

Hidayat, N. (2013). Pemeriksaan Pajak. (R. Toruan, Ed.). PT Elex Media Komputindo Kompas Gramedia.

Irawan, H. (2011). 10 Prinsip Kepuasan Pelanggan (Cetakan Ke). PT Elex Media Komputindo.

Ita Salsalina, L. (2012). Pengaruh Penerapan e-SPT Terhadap Efisiensi Pemrosesan Data Perpajakan: Survey Terhadap Pengusaha Kena Pajak pada KPP Pratama X, Bandung, Vol.4 No.2.

Lubis, I. (2011). Kreatif Gali Sumber Pajak tanpa Bebani Rakyat. Kompas Gramedia. Murtopo, P. (2011). Perpajakan. Jakarta: Mitra Wacana Media.

Pandiangan, L. (2008). Modernisasi \& Reformasi Pelayanan Perpajakan. Jakarta: PT. Elex Media Komputindo. 
Supranto. (2011). Manajemen Kepuasan. Jakarta.

Sugiyono. (2014). Metode Penelitian Kuantitatif Kualitatif. Bandung: Alfabeta.

Tumuli, A. K., \& et, al. (n.d.). Analisis Penerapan E-SPT dan E-Filing dalam Upaya Peningkatan Kepatuhan Wajib Pajak (Studi Kasus di Kantor Pelayanan Pajak Pratama Manado). 